\title{
Islamic Spiritual Capital Implementation at BMT UGT Sidogiri
}

\author{
Widita Kurniasari \\ Universitas Trunojoyo Madura, Madura, Indonesia \\ email: disertasidita@gmail.com
}

\section{Tjiptohadi Sawarjuwono}

Universitas Airlangga, Surabaya, Indonesia

email: tjiptohadi.unair@gmail.com

\section{Muhamad Nafik Hadi Ryandono}

Universitas Airlangga, Surabaya, Indonesia

email: widita81.wk@gmail.com

\begin{abstract}
The purpose of this study was to obtain an in-depth description of the implementation of the concept of Islamic Spiritual Capital at BMT UGT Sidogiri. The approach used in this research is Islamic phenomenology. This research explores events/phenomena and organizational culture at BMT UGT Sidogiri. This method helps to reveal how to implement Islamic Spiritual Capital in the culture of working at BMT UGT Sidogiri. The results showed that the importance of civilize Islamic Spiritual Capital was reflected through prayer discipline, time discipline and rule discipline. Uphold the work ethic of three -as in working, they are working hard, working smart and working sincerely. This work ethic involves the body, brain and heart. Islamic leadership is basically a belief that prioritizes the attributes of the STAFF (Siddiq, Tabligh, Amanah, Fathonah). Motivation in working is intended to worship, seek the blessing of Allah and become a charity hereafter so that the goal is not only for the world. So that, every employee has an Islamic commitment that is having the confidence to be loyal to the organization and istiqomah (steadfastness) at work.
\end{abstract}

Keywords: Islamic Spiritual Capital; Islamic Leadership; Work Motivation; Work Commitment

\begin{abstract}
Abstrak: Tujuan dari penelitian ini adalah untuk memperoleh gambaran yang mendalam tentang implementasi konsep Modal Spiritual Islam di BMT UGT Sidogiri. Pendekatan yang digunakan dalam penelitian ini adalah fenomenologi Islam. Penelitian ini mengeksplorasi peristiwa/fenomena dan budaya organisasi di BMT UGT Sidogiri. Cara ini membantu mengungkap bagaimana mengimplementasikan Modal Spiritual Islam dalam budaya kerja di BMT UGT Sidogiri. Hasil penelitian menunjukkan bahwa pentingnya modal kerohanian Islam yang beradab tercermin melalui disiplin shalat, disiplin waktu dan disiplin aturan. Menjunjung tinggi etos kerja tiga -sebagai dalam bekerja, mereka bekerja keras, bekerja cerdas dan bekerja dengan ikhlas. Etos kerja ini
\end{abstract}

Economica: Jurnal Ekonomi Islam - Volume 10, Nomor 2 (2019) 
Widita Kurniasari, Tjiptohadi Sawarjuwono, and Muhamad Nafik Hadi Ryandono

melibatkan tubuh, otak dan hati. Kepemimpinan Islam pada dasarnya adalah keyakinan yang mengutamakan atribut STAF (Siddiq, Tabligh, Amanah, Fathonah). Motivasi dalam bekerja dimaksudkan untuk beribadah, mencari ridho Allah dan menjadi sedekah akhirat agar tujuannya tidak hanya untuk dunia. Sehingga setiap karyawan memiliki komitmen islami yaitu memiliki kepercayaan diri untuk setia pada organisasi dan istiqomah (ketabahan) dalam bekerja.

Kata Kunci: Modal Spiritual Islam; Kepemimpinan Islam; Motivasi kerja; Komitmen Kerja 
Islamic Spiritual Capital Implementation at ...

\section{Introduction}

In the era of the current economic development, there is a new form of capital and is called spiritual capital. Woodberry (2003) states that spiritual capital is different from other capital which generally has material resources. Spiritual capital according to Zohar and Marshall (2004) is wealth that enriches the depth of aspects of our lives. Wealth that we get through the deepest meaning, the deepest value, the most fundamental goals, and the highest motivation and by finding ways to instill it in our lives and work. It was explained that spiritual capital is wealth we can live by.

Understanding of spirituality in Islam has a more kaffah meaning, unlike the secular understanding described by Zohar and Marshall (2004) and Woodberry (2003). Spirituality in Islam is guided by the guidance given by Allah SWT so as Muslims must ensure that everything he does is to get the blessing of Allah. Islam does not see spirituality separately from daily activities and business. Islamic spirituality is based on monotheism, affirming Allah because there is no God worthy of worship except Allah. Thus the Islamic Spiritual Capital intended in this study certainly will not be separated from the Islamic values of monotheism.

Research on spiritual intelligence is also carried out by Istiariani (2018) which proves that spiritual intelligence plays an important role in efforts to form and increase the ethical sensitivity of BNI Syariah internal auditors. Since spiritual intelligence is considered capable of being a filter in an effort to overcome the weakness of ethics and the strengthening of issues of audit failure as well as the manipulation of financial reports and the weakness of an organization's internal control system.

Islamic Spiritual Capital in Indonesia has been implemented in several Islamic financial institutions, one of which is Baitul Maal Wat Tamwil (BMT). BMT is a microfinance institution that operates according to sharia principles that function as an economic driving force in Islamic boarding schools. BMT

Economica: Jurnal Ekonomi Islam - Volume 10, Nomor 2 (2019) 
was developed on the initiative and initial capital of local community leaders based on the salaam economic system: safety (justice as the core), peace, and welfare (Hosen and Kartika, 2007).

BMT UGT Sidogiri was appointed in this study because BMG UGT Sidogiri is the largest sharia cooperative in Indonesia in 2019 and the $4^{\text {th }}$ largest cooperative of 100 Indonesian Large Cooperatives in 2017. The BMT UGT Sidogiri Cooperative also received three awards at the same time in 2017 as the Best IT Cooperative, the Cooperative with the Biggest Turnover and the Cooperative with the Biggest Assets (Muchtar, 2007). Based on the results of interviews with Director 1 of BMT UGT Sidogiri (2018), Ustadz Sholeh Wafi stated that BMT UGT Sidogiri had passed ISO 9001: 2015 management certification, which was conducted by the British Standard Institution in 2016.

Researchers are more focused on internal issues related to the concept of spiritual capital. BMG UGT Sidogiri internal problems such as Human Resources problems, namely dishonesty, embezzlement of money, indiscipline, lack of knowledge about cooperative economics and Islamic finance both in terms of employees and business partners. STAF characters which are Shiddiq (honest), Tabligh (Transparent), Amanah (trustworthy) and Fathonah (Professional) that must be owned by management and employees of BMG UGT Sidogiri have not been realized properly. The STAF character is a part of the concept of Islamic Spiritual Capital which must be present in BMT UGT Sidogiri. Human resources in BMT is one of the important factors that influence the business of BMT. Professional management and employees will be able to achieve the set revenue targets.

Based on the background above, the implementation of management and employee behavior of BMT UGT Sidogiri in developing their Islamic business should be a capital to achieve mutual prosperity. Then, the problem can be formulated, namely how to implement the concept of Islamic Spiritual Capital at BMT UGT Sidogiri. 
Islamic Spiritual Capital Implementation at ...

\section{Literature review}

\section{Islamic spiritual capital}

The concept of Islamic spiritual capital actually existed in the Qur'an and As-Sunnah before the concept of conventional spiritual capital emerged. However, the concept of conventional spiritual capital was first coined by several experts including Woodberry (2003), Zohar and Marshall (2004), then followed by Lowder (2006), Liu (2008), and Malloch (2010) and several other experts. Western experts agree that the concept of spiritual capital has no connection with religion or other belief systems.

Islamic spiritual capital does not see spirituality separately from daily activities. Muslims make sure that everything they do is to get the blessing of Allah. Islamic spirituality is based on monotheism, afflicting God because there is no god worthy of worship except Allah. Thus the Islamic spiritual capital intended in this study certainly will not be separated from the Islamic values of monotheism.

Islamic Spiritual Capital is a set of beliefs, role models (leadership), motivation, ethos and commitment embodied in virtue values guided by the Qur'an and Hadith of the Prophet Muhammad as well as being a basic foundation in human relations with the creator of Allah (hablumminallah) and human relations with each other (hablumminannas), as well as how to instill these virtue values in their lives and work.

Liu (2008) summarizes several definitions of spiritual capital in three categories including: (1) Religious capital, (2) The meaning of life, and (3) Attachment to God. The concept of spiritual capital emerged and developed from the concept of social capital. Not much discussed the topic of this spiritual capital. This concept illustrates the slice between economics and religion in classical works such as (Tawney, 1998), "Religion and the Rise of Capitalism" and (Weber, 2002) "The Protestant Ethics and the Spirit of Capitalism", is a way of thinking political economy about the economy and its development.

Economica: Jurnal Ekonomi Islam - Volume 10, Nomor 2 (2019) 
Widita Kurniasari, Tjiptohadi Sawarjuwono, and Muhamad Nafik Hadi Ryandono

\section{Islamic leadership}

Islamic Spiritual Capital which is reflected in Islamic leadership. The concept of leadership in the Qur'an contained in Surah An-Nisa verse 59. Prophet Muhammad clearly mentions the question of leadership in one of his words which is narrated in Sahih Bukhari from Ibnu Umar RA No. 893 that "Every one of you is a leader and will be held accountable for your leadership." Various leadership theories put forward by leadership teachers are found in the person and leadership of Prophet Muhammad. Some traits in the Prophet Muhammad that are very popular and become the motive for action in Islam are Shiddiq, Amanah, Tabliq and Fathanah (Hadari, 2001).

Shiddiq (honest) comes from the word shidq (honesty), the word siddiq is a form of emphasis (mubalaghah) and sadiq, which means people who are dominated by honesty (Tasmara 2004). Honesty is not a compulsion, but a calling from within, an attachment (commitment, aqad, i'tiqad) (Tasmara, 2004). Honesty in question is honesty in attitude, work and honesty in financial matters.

This honesty is one of the most important bases for building professionalism. Shiddiq in the context of Islamic leadership can be interpreted that a leader always behaves correctly and honestly, godly, values oriented, brave, tough, patient, wise, and sincere during his leadership period. Correct in making decisions in organizations that are strategic regarding the vision and mission, and effective and efficient in its implementation and operations in the field.

Amanah means trustworthy, responsible or credible. Amanah is loyalty to the commitment in carrying out the duties and obligations given to him. Amanah also means trustworthy, professional, disciplined, responsible, independent, skilled, tough, persistent, resilient, unyielding, and confident (Nasution, 2007). 
A leader must have a sense of responsibility, can be trusted in carrying out his leadership duties. This can be seen in his display of openness, readiness in responding to criticism and in serving his subordinates. He is able to do business; able to do the best for community service. He can avoid the reprehensible qualities. He is expected to avoid collusion, corruption and the like.

Tabligh means to convey. Leaders should be able to convey the truth at all costs. He will not be afraid of challenges, obstacles, obstacles as well as threats. As long as it is conveyed the truth is not only the position of the stakes but it can be relieved his soul for the sake of truth and benefit.

Indeed the ideal leadership is a derivation of the leadership of the Prophet Muhammad. The problem is the extent to which generations have not lost the direction of the inheritance of guidance that has been imprinted in the Prophet. The criteria that have been hinted at in the Qur'an below, if fulfilled, will inevitably approach expectations.

Fathonah means intelligent, meaning that leaders are expected to be able to solve problems, have the ability to find solutions, and have broad insights. Smart leaders are possible to take initiative carefully, precisely, and quickly. When faced with problems that occur in his leadership, he will respond. Islam was revealed to all humans and also as a mercy to the universe. An intelligent leader whose mind, emotions and heart can be expected to be able to provide guidance, advice, guidance, opinions and views for humanity according to God instructions.

\section{Work motivation}

Hasibuan (2001) revealed that motivation questions how to direct power and potential to want to work together productively to achieve and realize predetermined goals, want to work and enthusiastically achieve optimal results. Whereas Manullang and Manullang (2001) defines motivation as work done by a manager giving inspiration, enthusiasm, encouragement to 
others. In this case the employee to take actions. This encouragement aims to encourage employees so that they are excited and can achieve the results desired by the person.

The concept of spiritual motivation according to Chapra (2000) is similar to that put forward by Max Weber who developing western world is not driven by motivation from consumer value, but by motivation from creative value called the work ethic. Since Max Weber is a Protestant, the work ethic is called the Protestant ethos, that's the religious ethos (Nataatmaja, 2001). The religious ethos in question is a spiritual ethos that has advanced the economy in the western world, where actually the economic progress is driven by the strength of Protestant spiritual motivation.

The Qur'anic view of religious motivation is a motivation that has a basis of innocence in the nature of human creation. Humans feel the motivation in their hearts to encourage them to think and research, to find out the creator and creator of the universe. He then was compelled to worship, take sight and take refuge in Him and ask for help from Allah. Especially every time he gets a trial and the difficulties of his life increase for him. Because humans find security and peace in His protection and care (Najati, 2006).

\section{Previous research}

This research differs from previous studies in terms of research methodology using Islamic phenomenology. In addition, this research also wants to see Islamic spiritual capital reflected through Islamic leadership, Islamic work motivation and Islamic work commitment. The various previous studies are as follows:

Cavanagh and Bandsuch (2002) with the research title "Virtue as a Benchmark for Spirituality in Business" which uses action research methods. His research results show that the ability of spirituality to develop good moral habits has a positive impact on business. As a norm or benchmark to assist business people in determining spirituality appropriate for the workplace, it 
has been proposed that managers support their spirituality which promotes good moral behavior and character, because this spirituality will maximize the benefits of spirituality at work and minimize potential problems.

Malloch (2010) with the research title "Spiritual Capital and Practical Wisdom". Malloch uses the spiritual capital concept approach which will be explained using social capital concepts and empirical examples of virtues. What is needed by the company in order to succeed in winning the competition (competition) is through spiritual capital which contains virtue and morals from its human resources. Human faith is an important part of the values in business organizations. According to Malloch there are two virtues that have a positive impact on business, they are hard virtues and soft virtues. Hard virtues exemplified such as: leadership, courage, patience, perseverance, and discipline. While soft virtues are exemplified such as: justice, compassion, forgiveness, gratitude, and humility.

Yusuf (2011) with the research title "Effects of Spiritual Capital on Muslim Economy: The Case of Malaysia". In his research examines how spiritual capital can affect the economy of the community. His research focuses on how the Malay people together based on their Islamic beliefs have projected the economy of the community towards the world nation to seek excellence from the Islamic economy in the world. This research looks at three Islamic institutions in Malaysia which have direct and indirect effects on the economy of the Malay Muslim community and the overall effect in Malaysia in general. The institutions studied were Islamic financial institutions, Zakat and Waqaf institutions in Malaysia. The institutions tested were based on ACT (s) who founded it, which has been achieved through these Malay institutions in particular and Malaysia in general.

Tsafe and Rahman (2014) his research entitled "Effects Of Spirituality On Board Service Performance In Malaysian Microfinance Firms". This study explores and analyzes the extent to which the dimensions of Islamic spirituality explain the performance of service agencies in Malaysian 
microfinance institutions. Data were obtained from 63 respondents from questionnaires in 4 microfinance organizations. In this study it was found that the sharia spiritual values in the performance of the Malaysian Sharia microfinance service agency showed the importance of governance mechanisms in the process of corporate development. Malaysian Islamic microfinance institutions (IMFIs) can play an important role, namely providing the best assessment of the impact of sharia spirituality on measuring the performance of service roles that can achieve the dual goals of microcredit companies. This research contributes to spirituality from an Islamic perspective in terms of its application for performance improvement and can have an impact on poverty alleviation and the sustainability of IMFIs in future studies.

\section{Methods}

This study uses an Islamic phenomenology approach because it explains the phenomenon of human behavior experienced and seeks to explore the meaning and life experience of a number of people about an Islamic Spiritual Capital concept at BMT UGT Sidogiri which aims to achieve mutual benefit.

Phenomenology as an epistemology helps in finding knowledge especially in defining phenomena. The basic assumption of secular phenomenology is that the truth of knowledge only comes from experience based on consciousness. Based on this assumption, what is meant by phenomena is only limited to the reality that is realized and entered into human understanding. The concept of truth that is understood is secular that separates God, thought, and science issues and opposes anything that cannot be observed (revelation) (Al-Attas, 1995); (Choudhury, 2008); (Zakaria, 2012). For the phenomenology of Islam, God as the creator of an ideal reality.

Based on the ontological and epistemological assumptions above, Islamic phenomenology believes that truth is a holistic truth and is integral to two dimensions of truth, namely truth derived from evidence of natural 
phenomena and human life (verses of kauniyah) and evidence sourced from God through revelation (verses Kauliyah). The two sources of knowledge are one entity and can complement each other in the development of knowledge (Triyuwono, 2013). Furthermore Muhadjir (2000) explains that the integrative truth between science and revelation is complete truth and provides guidelines for scientists.

The Islamic paradigm is used to develop the methodology in this research. In addition to improving the basic assumptions of secular phenomenology based on Islamic values, development of conceptual components as a unit of analysis of phenomenological research is also carried out, including: intentionality, noema and noesis, intuition, and intersubjectivity Husserl (1970); Moustakas (1994) and Langdridge (2007) in (Niswatin, 2014).

This study uses surveys to obtain primary data from original or first sources. In this study, data were collected through in-depth interviews and participant observation with management and employees of BMT UGT Sidogiri in Pasuruan.

The subjects in this study are individuals who have a relationship between one person and another, or one case with another case in the management of Baitul Maal Wa Tamwil (BMT) and individuals who have special knowledge about Islamic values in the context of Islamic finance. Subjects based on experience in BMT UGT Sidogiri include the Chairperson, Director I and Director II of BMG UGT Sidogiri. Subjects based on knowledge of the object of research are scholars who have knowledge in interpreting the Qur'an and hadiths and have special knowledge about sharia economics.

The reason for choosing this informant is that opinion and information can be asked about how the implementation of Islamic Spiritual Capital is reflected in work motivation, work commitment and Islamic leadership in the management and employees of BMT UGT Sidogiri. 
Widita Kurniasari, Tjiptohadi Sawarjuwono, and Muhamad Nafik Hadi Ryandono

\section{Result and discussion}

\section{Implementation of the Islamic spiritual capital concept at BMT UGT}

\section{Sidogiri}

BMT UGT Sidogiri applies spiritual values in its business processes that feel very real when the author makes observations several times to the headquarters of the BMG UGT Sidogiri in Pasuruan. Those spiritual values have been implemented in daily work at BMT UGT Sidogiri. The basis of religious knowledge which is owned by most employees who are alumni of Islamic boarding schools is a major capital for them to make a living. Following is an explanation from Director I of BMT UGT Sidogiri, Ustadz Sholeh Wafi about the recruitment of BMT UGT Sidogiri employees (interview on 11 August 2018):

"The recruitment of BMT UGT Sidogiri employees is prioritized for Sidogiri Islamic Boarding School alumni, because this BMT was founded by alumni. BMT is also a means of alumni looking for fortune. In some areas where there are no Sidogiri boarding schools alumni, BMT works closely with local boarding schools. So that the boarding schools can distribute its alumni and BMT products will also be marketed by the boarding schools ulama/kyai. We are cooperating with Islamic boarding schools in influential areas in order to get support from these boarding schools."

The value of spirituality in its implementation in BMT UGT Sidogiri is guided by the spirit of Islam. In running a business in BMT UGT Sidogiri, the aim is to strive in the way of Allah SWT, so that it is not just a business for worldly profit. Following are the results of the interview with the head of the BMT UGT Sidogiri, KH. Mahmud Ali Zain (interview on 31 October 2018):

"Indeed, we cannot be separated from the spirit of religion, so this business is not just a business, not just seeking worldly benefits, yes, if I describe it, the spirit is in Surah Ash Shaff verse 10-11 that means do I need to show you, trade that can save you from painful torture. We have in the Articles of Association there are about our work ethic is "three-as", hard work, smart work, sincere work. Hard work is a body; the body must be healthy. Smart work is the brain. Sincere work is the heart, so how do we do business is a combination of three things. Healthy body, healthy mind, healthy heart." 
Based on an interview with Kyai Mahmud Ali Zain above, it appears that in the BMT business in UGT Sidogiri there are three things integrated, namely the heart, mind and body. Spiritual capital in the form of virtue values such as prayer discipline, time discipline and rule discipline was also emphasized by him, besides that BMT UGT Sidogiri employees must also always study and fill spiritual activities with concise lectures as he said the following:

"Hard work, smart work, sincere work. Now these three things are necessary, so in this case it is realized in the form of three-disciplines namely prayer discipline, time discipline, rule discipline. The point here is rules, but there needs to be support for these rules so that the rules are truly disciplined, time needs to be disciplined. Then, discipline at that time if you were not used to it was rather difficult, you need to be disciplined in prayer, still to recite first, then there is short lecture. Three times a week the short lecture, if you offer it every day after prayer."

To be able to enforce the discipline of prayer, time discipline and discipline must indeed start from the leader who gave the example first and must be supported by a system that is regulations that have been equipped with SOP (Standard Operation Procedure). According to Kyai Mahmud Ali Zain, the essence is discipline in the rules but it needs to be supported, first being trained by getting used to time discipline, then discipline when it can be if it is disciplined prayer.

Based on observations at BMT UGT Sidogiri that employees and administrators of BMT UGT Sidogiri in seeking sustenance are always followed by worship that always remembers Allah SWT, such as praying dhuha together, praying obligatory dhuhur and asr in congregation, dhikr and studying the Quran together, routinely performing pilgrimage. to the guardian's grave that reminds them of death. Following is the chart of the Implementation of Islamic Spiritual Capital at BMT UGT Sidogiri: 
Widita Kurniasari, Tjiptohadi Sawarjuwono, and Muhamad Nafik Hadi Ryandono

Figure 1. Implementation of Islamic Spiritual Capital at BMT UGT Sidogiri

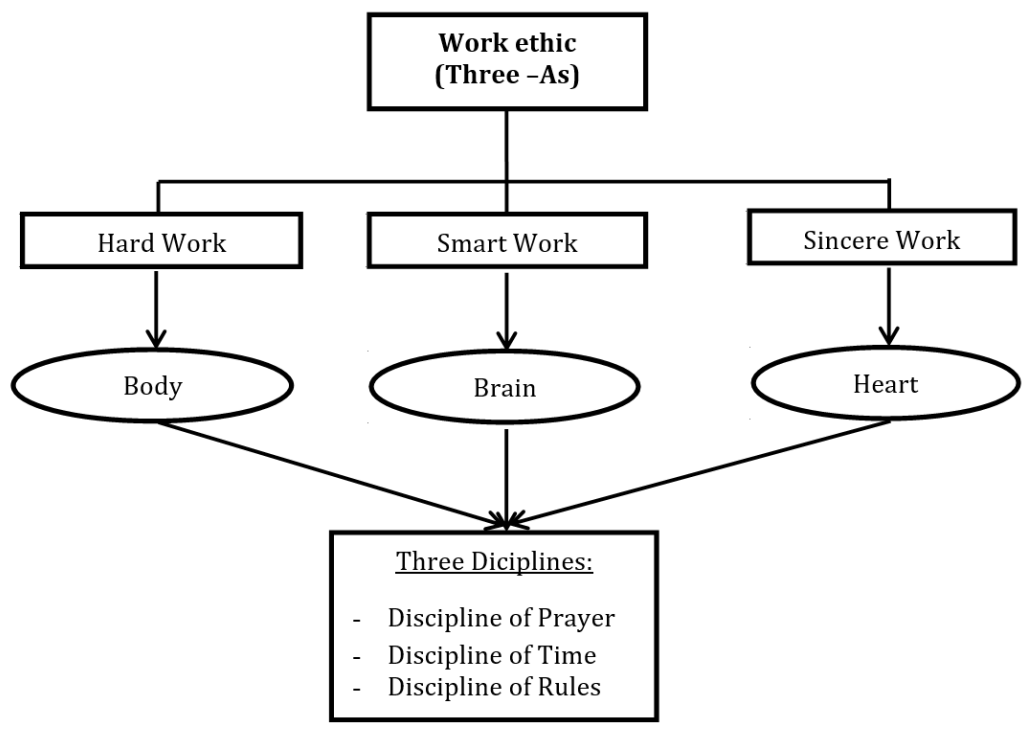

Source: Results of interview with KH. Mahmud Ali Zain (October 31, 2018)

Activities which have been conducted by employees and management of BMT UGT Sidogiri in looking for bounty of Allah, still not neglecting worship, and always remembering death. Humans are encouraged to seek wealth as much as possible, but with a process that does not forget death. In accordance with the word of Allah SWT in QS. At-Takatsur verse 1-2 which means: "Happiness has neglected you, until you enter the tomb".

Increasing the employees' faith of BMG UGT Sidogiri is carried out routinely and continuously. As the statement of Ustadz Sholeh Wafi, as follows:

"Increasing the employee's faith in BMT UGT Sidogiri is done with the obligatory prayers in congregation, once a month pilgrimage to the guardian's grave, routine recitation of Al Quran one juz divided for four people, praying dhuha together and at the end of each month conducting selametan khotmil Quran by eating together bought by the management and the board of directors. BMT UGT also always civilizes a sense of sharing, caring and empathy as a form of social action 
(amaliyah). Applying the cultural values of Siddiq (honest), Tabliq (conveying), Amanah (trust) and Fatonah (smart) in order to achieve the ideal of nation that is baldatun thoyyibatun wa robbul ghofur."

According to Jaza'iri (2013), moral is a strong condition in the soul, it appears the desire from it to do in the form of good or bad influenced by the education they have. If the condition is fostered to choose goodness, then it will become a character that will then lead to good action easily without coercion or what is called good moral. Islam proclaims on adherents to have good moral. Therefore, Islam measures a person's faith based on the virtues that exist in him/her, including good moral.

Spiritual capital in the form of virtue values at BMT UGT Sidogiri emphasizes the importance of working sincerely. Sincerity is from the heart, or it can also be said intention. Everything that is done in this world is merely to worship Allah SWT to stay away from His prohibitions and obey His commands, that is what is called sincerity (KH. Mahmud Ali Zain). According to his explanation that sincerity is in the heart, or termed intention, the intention is moved by the heart to do something. Allah moves the heart. We work because of Allah. This work has a lot of things that encourage. We must be enthusiastic, complete work and closing work. Because who orders me to work is Allah, so do not let the payment to move us to work. It is only the world, we get the world and the hereafter, we are paid and we get also reward from Allah.

At BMT UGT Sidogiri emphasizes a sincere heart. The most powerful motivation in working is sincere, not just to improve welfare in the world but when someone works sincerely because of Allah SWT then the payment is not only in the world but also in the hereafter. This sincere work has been included in the Articles of Association of BMT UGT Sidogiri. Kyai Mahmud Ali Zain also told that the first struggle to establish BMT was his sincere intention to fight for Islam. 
Widita Kurniasari, Tjiptohadi Sawarjuwono, and Muhamad Nafik Hadi Ryandono

According to Kyai Mahmud Ali Zain, when we sincerely struggle in the way of Allah, then there is a great force that drives us to achieve success. Indeed human needs endeavor but all the achievements obtained by BMT UGT Sidogiri are due to Allah's blessing. The importance of running lawful business with maximum effort and hard work that aims to seek the pleasure of Allah SWT. Rasulullah teaches us to pursue lawful business ( $a^{\prime} m a l$ ) or livelihood (ma'isyah) and according to the rules of Allah SWT.

\section{Islamic leadership at BMT UGT Sidogiri}

Islamic leadership is basically principle of trust. Frequently, it is a social contract (explicitly) between the leader and that is led. The following is excerpt of interview with KH. Mahmud Ali Zain on October 31, 2018 about Islamic leadership:

"Any leader, also that is led, in surah An-Nisa verse 58-59 that's mean about trustful. If you punish to determine a law, then you must be fair. Then the attitude is led, obedient, loyal. And one more if the leader who is authoritative, obeyed, loyal congregation, muthi'an, don't be the third, jazu'a always incapable, the leader is not capable to be followed, so the congregation only crashes into it (action), it may not. Imaaman matho'an, makmuman muthi'an, wa la takun tsalisan, the principles, we take the philosophy of life taking from the congregational prayer in terms of regulating, we take from the philosophy of the congregation."

Based on the results of interview with Kyai Mahmud Ali Zain above, a leader must have a fair character and can be a role model, so that he/she can easily influence, direct to subordinates. Therefore, related to the leadership of BMT UGT Sidogiri shows the existence of leadership based on Islamic values. This is demonstrated by leadership that implies integrity and fairness and imbued with the character of Murobbiun (educating), Irsyad (directing), Taushiyah (guiding) and Ta'awun (cooperation).

The educating (Murobbiyun) leadership is a form of leadership that provides education to subordinates. As a murobbi, an educator will prepare his/her students to be able to be creative, able to regulate, and maintain the 
results of his/her creation to bring benefits to him/herself, the community and the natural surroundings (Kusumawati, 2013).

The leadership process at BMT UGT Sidogiri in providing education to employees is carried out at regular weekly meeting activities to monitor target, personally mentoring to the employees who do not achieve the targets, providing training and sharing experiences gained from outside. This form of educational leadership is very dominant at the environment of BMT UGT Sidogiri. This happens because most of the leaders of BMT UGT Sidogiri come from community figures who come from Islamic environment. The existence of BMT UGT Sidogiri was early emergence of an environment that has a quite strong culture and nuances of Islam in that environment, a leader becomes a role model in carrying out various activities, so the leadership that educates at this BMT environment is very relevant for the progress of BMT.

The directing (Irsyad) leadership is a leadership that gives direction to subordinates in carrying out activities. Implementation of leadership that gives direction to employees in the environment of BMT UGT Sidogiri is done in the form of giving direction related to the targets and implementation of various cooperative policies that have been running, giving direction to employees who experience difficulties in their work, socializing the Standard Operational Procedure (SOP) and providing briefing in case of irregularities. This leadership model is carried out routinely every week to monitor targets. Each month the branch must submit an evaluation report every seventh.

The leadership which is based on the nature of guiding (taushiyah) is a leadership that provides guidance to subordinates. Implementation of the leadership of BMT UGT Sidogiri which provides guidance to employees is done at every routine weekly meeting, provides solutions to various problems that arise and in resolving conflicts between coworkers. The leadership model as mentioned above is very relevant in providing guidance based on Islamic values.

Economica: Jurnal Ekonomi Islam - Volume 10, Nomor 2 (2019) 
The leadership which is based on the nature of cooperation (ta'awun) is a leadership who likes to cooperate with subordinates. Implementation of leadership at BMT UGT Sidogiri in cooperation is done in the form of target determination of BMT. The leadership commitment that emphasizes cooperation is socialized at regular meeting agenda or at work meeting. This is in accordance with Islamic law that the success in managing BMT UGT Sidogiri depends on the ability of a leader to cooperate with subordinates.

Most of the employees at the headquarters of BMT UGT Sidogiri in Pasuruan almost $70 \%$ have part-time job as madrasa teachers or pesantren. So that their basic to become a leader already exists because a teacher is used to guiding and directing their students. The following is excerpt of interview with the Business Director, Ustadz Abdul Rokhim about leadership at BMT UGT Sidogiri, interview on October 31, 2018:

"The employees basic at BMT UGT are teachers, the teacher is used to being a leader, already trained to be a leader, already used to guide, direct, even in the capacity as santri or student when implemented in work, they can, how to talk to people, invite savings, invite transaction, and even many members join, they don't know BMT but know its ustadz. Being trust to ustadz, so the basic is the credit point for our business that can make rapid growth because of that individual trust."

These employees do have leadership, so they can guide and direct their congregation to practice Islam in kaffah, not only in terms of worship but also in terms of economics must be in accordance with sharia. As stated by Ustadz Abdul Rokhim (interview on October 31, 2018):

"In some cases, because individual employees who become ustadz, speakers are often invited to recitation, sometimes who have regular recitation, so that from the leadership bring congregation to be directed not only to listen to religious lectures, how to become Islamic in kaffah, not only in terms of worship but what about the economic side because what is meant by udkhulu fis silmi kaffah is not only religious matters but also economic must be in accordance with sharia.

According to Tasmara (2004) that the teachings of Islam are always coherent, have a systematic stage in each harokah. Likewise with leadership, then one of the values or views that must be done first is towards yourself 
(ibda binafsik). Any movement in the steps of a moslem will begin with his/her self-improvement (ibda binafsik) which then simultaneously gives influence to other parties which is a magnetic movement. The leadership attitudes that must grow in a moslem are a strong unity between faith and charity, between intention and reality which then manifests one.

BMT UGT Sidogiri in running its business always civilizes a sense of sharing, caring and empathy as a form of social action (amaliyah). Management also applies the culture of shiddiq, tabligh, amanah, fathonah in the cooperative leadership process.

\section{Motivation to work at BMT UGT Sidogiri}

Islamic spiritual motivation can be divided into 3 , namely motivation of aqidah, worship and muamalat. The aqidah motivation can be interpreted as an internal motivation that arises from one's faith (belief) that there is no God but Allah and faith in the angels of Allah, the Books of Allah, the Messengers of Allah, the last day and Qadha and Qadhar. Likewise, the worship motivation is the motivation in oneself to carry out the rules of Allah and all activities undertaken by a moslem in the context of worshiping Allah SWT. Whereas the muamalat motivation is an internal motivation to meet human needs based on spiritual moral strength so as to produce a religious performance inspired by Al-Qur'an and As-Sunnah.

Implementation of the employees motivation of BMT UGT Sidogiri in working is for worship has been applied everyday. The employees believe that every effort that is intended by the acts of worship will become the next charity. Their goal is to work not only to get salaries and bonuses, but sincerely expect the blessing of Allah SWT. As stated by Ustadz Abdul Rokhim, Business Director of BMG UGT Sidogiri (interview on October 31, 2018) as follows:

"so working is motivation, we point out that the work is worship, because everyone knows that every business activity that is intended by the deeds of worship, it will be charity hereafter, motivation how not to ask, so as not to be a thief, even with limitation, their work motivation is like that, not merely a business, right, not 
merely working to get a salary, and we always instill it indeed, so it has never been employees fluctuation here in terms of doing demonstration that they are lack of salary, late salary, nothing, because indeed we embed not only hard work, we continue to embed to work sincerely."

An order that tells a moslem to work, such as being an entrepreneur, so that with income he/she can give alms. But when you cannot become an entrepreneur, another option is to become a competent employee so that it can provide added value to the company where you work. Some of the income earned as an employee can be given away. So that every Muslim must give alms to be able to provide added value or benefits wherever he/she is.

Jabir radhiyallahu'anhuma said that the Prophet Muhammad said: "The best of human beings among you are the most useful human beings." The hadith is approved by al-Albani in Shahihul Jami' (no. 3289). Another verse in Al Qur'an implies that quality Human Resources is like a good tree. Allah says in QS. Ibrahim [14] verse 24-25 which means "Have you not considered how Allah presents an example, [making] a good word like a good tree, whose root is firmly fixed and its branches [high] in the sky? (24), It produces its fruit all the time, by permission of its Lord. And Allah presents examples for the people that perhaps they will be reminded (25)".

If a good Human Resource (HR) is compared to a good tree, it means that the HR must have a strong faith and good life values. The purpose of the branch (towering) to the sky can be interpreted as a tree that can be a good direction (compass). Human Resources (HR) is like that can be used as an example for others. The tree will give its fruit every season with the permission of its Lord, it can be interpreted that the good human resources always give alms from the sustenance it receives. Allah says in QS. Ali Imran verse 134 which means: "Who spend [in the cause of Allah] during ease and hardship and who restrain anger and who pardon the people - and Allah loves the doers of good."

In the science of strategic management, there is a management strategy called the core competence strategy (core competence strategic). the core 
competence strategy is a strategy to have the core capabilities that are actually owned by a company. With this core capability, a company can run, own and produce various products, create a series of businesses and so on (Orgianus, 2012).

This core competence strategy is like a tree as in the verses of Al-Qur'an in Surah Ibrahim verse 24-25. Suppose a tree trunk is the core product. The branches and twigs are the business units. While the leaves, flowers and fruit are the end product. The visible part is not the most important part of a tree. But the most important part is not visible, because it is in the soil called the root. This root is called core ability (core competence). This root which gives nourishment to the tree and preserves the tree. This core ability which is likened to roots is rarely replicable, because of its hidden location. Likewise with core competence, it is difficult to imitate because its capabilities are hidden (Orgianus, 2012).

Likewise, the employees' core competence of BMT UGT Sidogiri who has high spiritual capital values. The employees are motivated to work professionally, not only for worldly matters such as matters of position, salary or career but they also think of the afterlife in the form of a missionary struggle about Islamic values. The explanation of ustadz Abdul Rokhim about professional work motivation (interview on October 31, 2018):

"Yes, we are trying to be more professional, indeed the culture of this employee has a collaboration value fid dunya hasanah wa fil akhiroti hasanah, where we work not only in matters of position, salary or career but the values of the afterlife in the form of struggle. That's why, our work hours especially in Branches, until 13.30, in the afternoon they teach to madrasa or pesantren, so even though in pesantren or madrasa the salary a month is only 200,000-250,000 but now they have worked at BMT, they don't complain too much, especially when Madrasa diniyyah lacks teachers. So it is not easy to recruit employees to want to be staff in the center, it is not easy, that is, because they have preaching routines, giving recitation, giving sermon."

Based on the above interview fragment that the employees of BMT UGT Sidogiri are included as valuable employees. The purpose of valuable 
employees is employees who not only have knowledge, but also have faith that is practiced in their daily lives. Through the practice of knowledge and faith in daily work, the employees inspire people around them so that many emulate their actions. This is a highly commendable act in Islam, the Prophet SAW said, "You cannot be jealous except for two people, firstly, someone whom Allah gives knowledge which is practiced then taught to others, secondly, someone whom Allah gives wealth, which is with wealth the upholding of the religion of Allah." (HR Muslim, Shahih Muslim No.1352).

\section{Commitment to work at BMT UGT Sidogiri}

Islamic commitment is basically a form of identification of loyalty and involvement expressed by employees of the organization or unit. Islamic commitment based on aqidah is a commitment that gives birth to a form of vitality and enthusiasm to achieve goals. The commitment implementation is carried out in the form of employee involvement in all operational targets of BMT UGT Sidogiri. Regarding the target, the following is the results of interview with the Director I of BMG UGT Sidogiri, Ustadz Sholeh Wafi (interview on August 11, 2018):

"Targets made for branches are a combination of top down and buttom up. There is negotiation from the branch for the target given by the head office. From the targets that have been set in the break down monthly, weekly to daily so that the evaluation is also daily. This is to facilitate the achievement of targets, namely by daily evaluation, especially in terms of funding (fund raising). Distribution of financing is also conducted by break down per AO (Account Officer) on duty and also monitored every day to achieve its targets. So that all employees here are target based."

The Islamic Commitment of the employees of BMT UGT Sidogiri who are perceived by employees as seen from akad shows that the Islamic commitment of these employees has a binding commitment to the organization. Likewise, the Islamic commitment of the employees of BMT UGT Sidogiri who are perceived by employees as seen from i'tikad shows that the Islamic commitment of these employees has an attitude or behavior that leads 
to a believed direction. In connection with the i'tikad commitment to BMT UGT Sidogiri, the following is the results of interview with the Director I of BMT UGT Sidogiri, Ustadz Sholeh Wafi (interview on August 11, 2018):

"BMT UGT Sidogiri applies a special strategy to sell financing with margins that are more expensive than KUR (People's Business Credit) banking, namely by explaining that there is no Al Qur'an or Al Hadith that limits the percentage of profit taking. The margins at BMT are higher because the benefits at BMT is more, if members take financing at BRI only for the benefit of the world, even containing usury, but if taking financing at BMT, the members will contribute a part of the profits for the benefit of preaching and education indirectly."

The Islamic Commitment of the employees of BMT UGT Sidogiri who are perceived by employees as seen from istiqomah shows that the Islamic commitment of these employees has been able to control themselves and manage emotion effectively and have passionate integrity. In connection with the istiqomah commitment to BMT UGT Sidogiri, the following is the results of interview with the Director I of BMT UGT Sidogiri, Ustadz Sholeh Wafi (interview on August 11, 2018):

"When financing is problematic, a persuasive approach is taken, including praying for. Usually not until the execution, has been completed. For collateral in the form of vehicle, sometimes asking for police assistance to find a unit that is usually mortgaged."

To instill a commitment in each individual employees of BMT UGT Sidogiri, the following is employee's pledge that is read every Wednesday after Dhuha prayer which always reminds employees to work professionally and always upholds the values of honesty, trust, transparent, and obedience to the Articles of Association and rules of Cooperative:

"Verily, my prayers, my worship, my life and my death, are only for Allah, Lord of Nature. I, employee of BMT UGT Sidogiri, will always: Work Hard, Work Smart, and Work sincerely for the benefit of cooperatives And will always be: Honest, Trust, Transparent, Professional, and Obey the Articles of Association and Rules of Cooperative".

Based on the document of the employee's pledge above, it can be concluded that the employees of BMT UGT Sidogiri promise in each individual 
that all activities of worship, life and death are only to achieve the pleasure of Allah SWT. So that every action that violates the rules or orders of Allah SWT will always be avoided. The employees try to always work hard, smart and sincere because they believe that all their activities in this world will be accounted for in the hereafter.

\section{Conclusion}

The implementation of the Islamic Spiritual Capital concept that is reflected in Islamic leadership, motivation to work and commitment to work at BMT UGT Sidogiri is realized by management by applying the culture of shiddiq (honest), tabligh (transparent), amanah (trust) and fathonah (professional) in the cooperative leadership process . Motivation of the management and the employees of BMT UGT Sidogiri in working is to worship Allah SWT. The management and the employees believe that every effort that is intended by the deeds will become the next charity. The management and the employees work not only to get salaries and bonuses, but sincerely expect Allah's blessing. The Islamic Commitment which is based on aqidah is a commitment that gives birth to a form of vitality and enthusiasm to achieve goals. The commitment implementation is carried out in the form of management and employees involvement in all operational targets of BMG UGT Sidogiri.

The limitation in this research is the Islamic Spiritual Capital model which is reflected through the Islamic leadership concept, work motivation and commitment in understanding BMT UGT Sidogiri is still at the initial level of ideas. Thus, further research is needed to develop the Islamic Spiritual Capital model at BMT.

The the Islamic Spiritual Capital Model of the results of this research require further and comprehensive study with different research approaches and subjects. This will provide a more specific figure and concept about the application of Islamic Spiritual Capital in kaffah. The values contained in the 
Islamic Spiritual Capital Implementation at ...

Islamic Spiritual Capital (ISC) model need to be socialized in other institutions in the field of finance, education, social and so on.

\section{References}

Al-Attas, Syed Muhammad Al-Naquib. 1995. Prolegomena To The Metaphysics of Islam, An Exposition of The Fundamental Elements of The Worldview of Islam. Kuala Lumpur: International Institute of Islamic Thought and Civilization (ISTAC).

Antonio, Syafi'i. 2012. Nsiklopedia Leadership \& Manajemen Muhammad SAW "The Super Leader Super Manager". Kepemimpinan Dan Pengembangan (Self Leadership \& Personal Development). Cetakan Ke. Jakarta: Tazkia Publishing.

Cavanagh, Gerald F., and Mark R. Bandsuch. 2002. "Virtue as a Benchmark for Spirituality in Business." Journal of Business Ethics 38 (1-2): 109-17. https://doi.org/10.1023/A:1015721029457.

Chapra, Muhammad Umar. 2000. Islam Dan Pembangunan Ekonomi. Jakarta: Gema Insani.

Choudhury, Masudul Alam. 2008. "Islam Versus Liberalism: Contrasting Epistemologi Inquiry." International Journal of Social Economics 35 (4): 239-68.

Furtwenger, Dale. 2003. Penilaian Kinerja: Menguasai Keahlian Yang Anda Perlukan Dalam 10 Menit. Yogyakarta: Andi Press.

Hadari, Nawawi. 2001. Kepemimpinan Menurut Islam. Yogyakarta: Gadjah Mada University Press.

Hasibuan, Malayu S. P. 2001. Manajemen Sumber Daya Manusia. Jakarta: Bumi Aksara.

Hosen, M. H, and S Kartika. 2007. Tuntunan Praktis Menggunakan Jasa Perbankan Syariah. Jakarta: Pusat Komunikasi Ekonomi Syariah.

Husserl, E. 1970. The Crisis of European Sciences and Transcendental Phenomenology. An Introduction to Phenomenological Philosophy. Evanston: Northwestern University Press.

Istiariani, Irma. 2018. "Pentingnya Kecerdasan Emosi Dan Spiritual Terkait Isu Sensitivitas Etika Auditor (Studi Kasus Pada Internal Auditor BNI

Economica: Jurnal Ekonomi Islam - Volume 10, Nomor 2 (2019) 
Widita Kurniasari, Tjiptohadi Sawarjuwono, and Muhamad Nafik Hadi Ryandono

Syariah)." Economica: Jurnal Ekonomi Islam 9 (2): 263. https://doi.org/10.21580/economica.2018.9.2.2720.

Jaza'iri, Syaikh Abu Bakar Jabir Al. 2013. Minhajul Muslim: Pedoman Ideal Seroang Muslim. Terjemahan Oleh Andi Subarkah. Surakarta: Insan Kamil.

Langdridge, Darren. 2007. Phenomenological Psychology: Theory, Research and Methods. New Jersey: Prentice Hall.

Liu, Alex. 2008. "Measuring Spiritual Capital as a Latent Variable Defining Spiritual Capital as Religion Capital." http://www.researchmethods.org/4capital.htm.

Lowder, B. T. 2006. "A Ghost in the Machine: The Important Role of Workplace Spirituality." SSRN 932811.

Malloch, Theodore Roosevelt. 2010. "Spiritual Capital and Practical Wisdom." Journal of Management Development 29 (7): 755-59. https://doi.org/10.1108/02621711011059194.

Manullang, M, and Marihot Manullang. 2001. Manajemen Sumber Daya Manusia. Jakarta: Ghalia Indonesia.

Moustakas, Clark. 1994. Phenomenological Research Methods. California: Sage.

Muchtar, Irsyad. 2007. 100 Koperasi Besar Indonesia. Jakarta: Peluang.

Muhadjir, Noeng. 2000. Metode Penelitian Kualitatif. Yogyakarta: Rake Sarasin.

Najati, Muhammad Utsman. 2006. Kecerdasan Emosional Dalam Kitab An Nabawiy Wa Ilman Nafs. Bandung: Pustaka Hidayah.

Nasution, Chaerul Alwan. 2007. "Makalah Kuliah Umum Manajemen Perusahaan Islami." Surabaya.

Nataatmaja, Hidayat. 2001. Intelegensi Spiritual. Jakarta: Perenial Press.

Niswatin. 2014. "Iman Sebagai Konsep Dasar Penilaian Kinerja Bank Syariah: Studi Fenomenologi Islam." Universitas Brawijaya.

Orgianus, Yan. 2012. Moralitas Islam Dalam Ekonomi Dan Bisnis. Bandung: Penerbit Marja.

Tasmara, Toto. 2004. Membudayakan Etos Kerja Islam. Cetakan Ke. Jakarta: Gema Insani.

Tawney, R. H. 1998. Religion and the Rise of Capitalism. New Jersey: Transaction Publishers. 
Triyuwono, Iwan. 2013. "Makrifat Metode Penelitian Kualitatif Dan Kuantitatif Untuk Pengembangan Disiplin Akuntansi." In Simposium Nasional Akuntansi Ke-16. Manado.

Tsafe, Bashir Mande, and Rashidah Rahman. 2014. "Effects of Spirituality on Board Service Performance in Malaysian Microfinance Firms." Journal of Finance, Accounting and Management 5 (1): 88. https://doi.org/10.5829/idosi.mejsr.2013.18.5.11908.

Weber, Max. 2002. The Protestant Ethic and the Spirit of Capitalism: And Other Writings. London: Penguin Classics.

Woodberry, R. D. 2003. "Researching Spiritual Capital: Promises and Pitfalls." In The Paper for Spiritual Capital Planning Meeting.

Yusuf, Muhammad Bashir. 2011. "Effects of Spiritual Capital On Muslim Economy: The Case of Malaysia." Research on Humanities and Social Sciences 1 (2): 23-41.

Zakaria, Wan Fariza Alyati Wan. 2012. "Fenomenologi Dan Tradisi Liberalisme Barat: Cabaran Dan Peranan Intelektual Muslim Di Asia Tenggara."

Zohar, Danah, and I N Marshall. 2004. Spiritual Capital: Wealth We Can Live By. 1st Ed. Danah Zohar, Ian Marshall. London: Bloomsbury. 
Widita Kurniasari, Tjiptohadi Sawarjuwono, and Muhamad Nafik Hadi Ryandono 